\title{
COMPARING THE ENZYME REPLACEMENT THERAPY COST IN POST PANCREATECTOMY PATIENTS DUE TO PANCREATIC TUMOR AND CHRONIC PANCREATITIS
}

\author{
Anna Victoria FRAGOSO', Martha Regina PEDROSO², Paulo HERMAN² and \\ André Luis MONTAGNINI²
}

Received 13/10/2015 Accepted 13/1/2016

\begin{abstract}
Background - Among late postoperative complications of pancreatectomy are the exocrine and endocrine pancreatic insufficiencies. The presence of exocrine pancreatic insufficiency imposes, as standard treatment, pancreatic enzyme replacement. Patients with chronic pancreatitis, with intractable pain or any complications with surgical treatment, are likely to present exocrine pancreatic insufficiency or have this condition worsened requiring adequate dose of pancreatic enzymes. Objective - The aim of this study is to compare the required dose of pancreatic enzyme and the enzyme replacement cost in post pancreatectomy patients with and without chronic pancreatitis. Methods - Observational cross-sectional study. In the first half of 2015 patients treated at the clinic of the Department of Gastrointestinal Surgery at Hospital das Clínicas, Universidade de São Paulo, Brazil, who underwent pancreatectomy for at least 6 months and in use of enzyme replacement therapy were included in this series. The study was approved by the Research Ethics Committee. The patients were divided into two groups according to the presence or absence of chronic pancreatitis prior to pancreatic surgery. For this study, $P<0.05$ was considered statistically significant. Results - The annual cost of the treatment was $\mathrm{R} \$ 2150.5 \pm 729.39 ; \mathrm{R} \$ 2118.18 \pm 731.02$ in patients without pancreatitis and $\mathrm{R} \$ 2217.74 \pm 736.30$ in patients with pancreatitis. Conclusion - There was no statistically significant difference in the cost of treatment of enzyme replacement post pancreatectomy in patients with or without chronic pancreatitis prior to surgical indication.

HEADINGS - Pancreatectomy. Enzyme replacement therapy. Chronic pancreatitis.
\end{abstract}

\section{INTRODUCTION}

Pancreatectomy is the total or partial resection of the pancreas and is the major treatment modality for many benign and malignant pancreatic and peripancreatic diseases. In many tertiary referral centers, pancreaticoduodenectomy is now performed with complication rates less than $40 \%$ and with death rates of $5 \%$ or lower. As indications for pancreatectomy have expanded to include many benign or borderline lesions, this raises issues for long-term survivors $^{(7,17,26,28,37)}$.

Only about 10 percent of patients with pancreatic cancer are eligible for the procedure and pancreatic ductal adenocarcinoma is the most common epithelial exocrine pancreatic tumor, representing more than 85 per cent of all malignant pancreatic tumors. In series of surgical resections, $80 \%-90 \%$ of tumors are located in the head of the gland ${ }^{(1,25,40)}$.

Pancreatic cancer is the most common periampullary adenocarcinoma. In different series of resected periam- pullary cancers, pancreatic cancers accounted for approximately $60 \%$, ampulla of Vater and distal bile cancers accounted for $10 \%$ to $20 \%$ each, and duodenal cancers accounted for 3\% to $7 \%$. Riall et al. found that $65 \%$ of 5 -year survivors survived 5 more years, bringing them to the 10-year postresection landmark ${ }^{(31,40,41)}$.

In chronic pancreatitis, pancreatic surgery is indicated when patients have untreatable pain ${ }^{(12,15,18,24)}$. Hereditary form of chronic pancreatitis represents $5 \%-10 \%$ of those affected and is also an important aetiological feature in pancreatic cancer ${ }^{(1,9,11,21,36,38)}$.

It is known that even partial pancreatic resections can result in impairment of endocrine and exocrine pancreatic function.

Exocrine pancreatic insufficiency (EPI) is caused by inadequate or defective secretion of enzymes ${ }^{(1,14,28)}$. The severity of postoperative EPI have functional and organic causes and varies with the extent of the resection, the functional capacity of the remaining gland and the changes in intestinal physiology ${ }^{(23,29,32,33)}$.

Declared conflict of interest of all authors: none

Financial support: This work was supported by Fundação de Amparo à Pesquisa do Estado de São Paulo (FAPESP). Processo n 2014/17495-5. Grant \#2014/17495-5, São Paulo Research Foundation (FAPESP).

Programa de Pós Graduação Ciências em Gastroenterologia, Faculdade de Medicina, Universidade de São Paulo, São Paulo, SP, Brasil. 2 Departamento de Gastroenterologia, Hospital das Clínicas, Faculdade de Medicina da Universidade de São Paulo, SP, Brasil.

Correspondência: Anna Victoria Fragoso. Hospital das Clínicas da Faculdade de Medicina da USP. Rua: Dr. Enéas de Carvalho Aguiar, 255, $9^{\circ}$ andar, sala 9074 . Cerqueira Cesar - CEP: 05403-900 - São Paulo, SP, Brasil. E-mail: annavfragoso@usp.br 
A long-term study with a 14 year follow-up shows that $80 \%$ of patients with chronic pancreatitis have exocrine insufficiency as a late complication of the surgery ${ }^{(35)}$.

Once patients are diagnosed with EPI, the pancreatic enzyme replacement is the standard treatment, regardless of the etiology of failure. Several authors show that pancreatic enzyme replacement after a resection improves absorption of nutrients, the quality of life and nutritional status of patients ${ }^{(15,16,30,32,39)}$.

Patients with chronic pancreatitis may have worse EPI than others that underwent pancreatectomy. It is known that $32 \%-41 \%$ of patients with chronic pancreatitis present with malabsorptive symptoms prior to surgical intervention ${ }^{(22)}$. After additional loss of the pancreatic tissue, it can be expected that EPI will worsen and these patients will need higher doses of pancreatic enzyme supplementation ${ }^{(4)}$.

What is not clear yet, is if the long term remaining pancreatic exocrine function after partial pancreatic resection is diferent in patients with or without previous chronic pancreatitis. Nordback and Neoptolemos have shown that enzyme replacement begins immediately after pancreatic resection, the surgeon's discretion, without examinations, according to the location and area of resection. Inadequate enzyme replacement doses can result in unnecessary costs ${ }^{(15,27)}$. Furthermore, several authors have demonstrated that post resection pancreatic enzyme replacement improves absorption of nutrients and thus the quality of life and nutritional status of patients ${ }^{(15,16,30,39)}$.

The aim of this study is to compare the amount and cost of enzyme replacement therapy in these patients.

\section{METHODS}

A tranversal observational study of patients submited to pancreaticoduodenectomy (PDT) or gastrodueodenopancreatectomy (GDT), carried out through the revision of the medical records of patients who were attended at the clinic of the Department of Gastrointestinal Surgery at Hospital das Clínicas, Universidade de São Paulo, Brasil. Data were collected in the first half 2015. The study was approved by the local Ethics Committee.

The inclusion criteria were: age $\geq 18$, with at least 6 months follow up after pancreatectomy and under enzyme replacement therapy.

The variables age, gender, date of surgery, weight, height and lipase units consumed per day were collected from the medical records. We sought to identify the dose adjustment criteria, through the medical management recorded in medical records.

Patients were divided in two groups considering the pancreatectomy indication: tumor or chronic pancreatitis.

The cost of enzyme replacement therapy was calculated based on the amount of lipase units consumed per day and the cost of Creon ${ }^{\circledR}$ capsules $(10,000$ and 25,000$)$ reported by the Pharmacy Division of the Hospital. The conversion of the actual dollar value was accomplished by using the dollar value of the period, US\$3.20.
Variables were compared using T-student test for independent averages. For this study, $P<0.05$ was adopted as statistically significant. To calculate the $\mathrm{p}$ value for gender the Fischer test was used, so the $\mathrm{p}$ value represents the gender and not male/ female separately. To calculate the $p$ value for age (median) the Wilcoxon test was used.

\section{RESULTS}

A total of 77 patients fit the inclusion criteria and they all were included in this study; $67.5 \%$ tumor, $32.5 \%$ chronic pancreatitis; $51.9 \%$ male, $48.1 \%$ female; the median age was 66.8 years (range 25-89). The average follow up time was $154 \pm 81$ months, body mass index (BMI) was $23.67 \pm 4.20$ $\mathrm{kg} / \mathrm{m}^{2}$ (Table 1).

The 'tumor' group is composed of 52 patients; $38.5 \%$ were male; $61.5 \%$ female; median age 72.2 years $(35-89$ years). Average time postoperatively $154 \pm 75$ months, BMI $24.30 \pm 4.77 \mathrm{~kg} / \mathrm{m}^{2}$ (Table 1).

The 'chronic pancreatitis' group consists of 25 patients; $80 \%$ were male; $20 \%$ female; median age 59.6 years (26-76 years). Average time postoperatively $154 \pm 94$ months, BMI $22.37 \pm 2.23 \mathrm{~kg} / \mathrm{m}^{2}$ (Table 1).

It was observed a statistically significant difference between the variables age $(P=0.0004697)$, gender $(P=0.0007018)$ and BMI $(P=0.018)$.

The dose adjustment protocol is based on clinical symptoms reported by the patient and objective methods were not used.

Daily consumption of lipase was $85,000 \pm 56,507$ units/ day; in tumor group $83365 \pm 30626$ units/day; 88400 in pancreatitis group \pm 30609 units/day. The cost of enzyme replacement treatment was US\$ 6881,63 $\pm 2334,04 /$ year; US\$ $6778,19 \pm 2339,26 /$ year in the tumor group; US\$ 7096,78 \pm $2356,17 /$ year in pancreatitis group. There is no statistically significant difference between the daily lipase consumption between groups $(P=0.50)$ or the annual cost of replacement enzymes $(P=0.58)$ (Table 2$)$.

TABLE 1. Demographic and clinic characterization of post pancreatectomy patients

\begin{tabular}{lcccc}
\hline Variable & $\begin{array}{c}\text { Tumor } \\
\mathbf{n}=52\end{array}$ & $\begin{array}{c}\text { Chronic } \\
\text { pancreatitis } \\
\mathbf{n}=25\end{array}$ & $\boldsymbol{P}$ value & $\begin{array}{c}\text { Total } \\
\mathbf{n}=77\end{array}$ \\
\hline Age & 72.2 & 59.6 & $<0.05$ & 66.8 \\
Gender & $20(38.5 \%)$ & $20(80 \%)$ & $<0.05$ & \\
Male & $32(61.5 \%)$ & $5(20 \%)$ & & $37(51.9 \%)$ \\
Female & $154 \pm 75$ & $154 \pm 94$ & 1 & $154 \pm 81$ \\
$\begin{array}{l}\text { Postoperative } \\
(\text { months })\end{array}$ & $24.30 \pm 4.77$ & $22.37 \pm 2.23$ & $<0.05$ & $23.67 \pm 4.20$ \\
BMI $\left(\mathrm{kg} / \mathrm{m}^{2}\right)$ & & & & \\
\hline
\end{tabular}


TABLE 2. Comparison of enzyme replacement therapy cost in patients post pancreatectomy due to tumor or chronic pancreatitis

\begin{tabular}{|c|c|c|c|c|}
\hline Variable & $\begin{array}{c}\text { Tumor } \\
\mathrm{n}=52\end{array}$ & $\begin{array}{c}\text { Chronic } \\
\text { pancreatitis } \\
\mathrm{n}=25\end{array}$ & $P$ value & $\begin{array}{l}\text { Total } \\
\mathrm{n}=77\end{array}$ \\
\hline $\begin{array}{l}\text { Lipase } \\
\text { units/per } \\
\text { day }\end{array}$ & $\begin{array}{l}83365 \pm \\
30626\end{array}$ & $\begin{array}{l}88400 \pm \\
30609\end{array}$ & 0.50 & $\begin{array}{l}85000 \pm \\
56507\end{array}$ \\
\hline $\begin{array}{l}\text { Enzyme } \\
\text { replacement } \\
\text { therapy } \\
\text { cost/year } \\
\text { (US\$) }\end{array}$ & $\begin{array}{l}6778.19 \pm \\
2339.26\end{array}$ & $\begin{array}{l}7096.78 \pm \\
2356.17\end{array}$ & 0.58 & $\begin{array}{l}6881.63 \pm \\
2334.04\end{array}$ \\
\hline
\end{tabular}

\section{DISCUSSION}

The EPI causes poor digestion of food and poor absorption of nutrients, leading to weight loss, and steatorrhea, abdominal pain (fecal fat excretion $\geq 6 \mathrm{~g}$ per day). It is also associated with deficiency of fat-soluble vitamins (A,D,E and $\mathrm{K}$ ), magnesium, calcium and essential fatty acids, which cause symptoms such as night blindness and osteoporosis ${ }^{(6,30,33,34)}$. The EPI is often associated with diabetes mellitus ${ }^{(14)}$. Considering the complication rates of EPI, patients may have significant impairment of quality of life $(\mathrm{QOL})^{(2,27,28)}$. Several studies show that the QOL has greater commitment postoperative immediate and mediate period.

Our study found that there is no statistically significant difference between the cost of the enzyme replacement therapy in patients with and without chronic pancreatitis prior to pancreatectomy.

Previous studies suggested that the level of EPI is determined by clinical symptoms and that the pancreatic enzyme dose is adjusted according to the clinical response of patients. To optimize fat absorption, pancreatic enzyme replacement therapy requires and, therefore, should be adjusted in relation to disease severity and clinical response. Based on persistent signs and symptoms of malabsorption or adverse events or based on the subjective evaluation of the treating physician, the prescriber is routinely adjusting the enzyme doses. Currently there are no guidelines in clinical practice for monitoring the efficacy of enzyme replacement therapy and determining a need for dose adjustment ${ }^{(6,8,13)}$.

The diagnosis of EPI by clinical signs (increased number of evacuations, weight loss, steatorrhea, flatulence) is not efficient, since they manifest themselves only when $90 \%-95 \%$ of the excretion of enzymes is compromised ${ }^{(19)}$.

Mild to moderate EPI is often neglected or not sought and represents a major problem, since no optimization of the exocrine function at this stage can significantly undermine the general health ${ }^{(16)}$.

The gold standard for diagnosing malabsorption of fat is the fat balance in the feces over 72 hours. To carry out this examination the patient should be submitted to a diet with control of fat content for 3 days, collect and store refrigerated all the evacuated volume and then forward it to the quantification of fat in the stool. All this makes the laborious routine procedure, unreliable, impractical, unpleasant and uncomfortable ${ }^{(3)}$. Because of these difficulties this test is rarely used in clinical practice.

As an alternative to quantitative measurement of fat in stools, fecal elastase test (FE-1) was introduced as an indirect method, user-friendly, accurate and non-invasive assessment of pancreatic function ${ }^{(29)}$. It is an examination of high cost and not always available throughout the health system.

In this study, the group who had surgical indication due to chronic pancreatitis is predominantly composed of men and is also a younger group than the 'tumor'. Chronic pancreatitis is the result from the complex interactions of various environmental and genetic factors, yet, in most cases the disease is the result of chronic alcohol abuse. This can be explain why the group is predominantly made up of young men ${ }^{(12,30)}$.

Despite the statistically different BMI in these groups, both are eutrophic. The BMI alone is not enough to determine the nutritional status of the patient. This population needs a detailed nutritional assessment once a poor nutritional status is one of indicators of EPI, since the loss of the exocrine function leads to poor absorption and hence weight loss ${ }^{(6,30,33,34)}$, so we can infer that our patients with pancreatitis have a more severe exocrine insufficiency. Both groups have the same follow-up and pancreatic enzyme dose.

These controversial findings corroborate the need to stratify the degrees of insufficiency to better treat patients. Patients may be being over treated and consequently harmed, since among the side effects of using pancreatic enzymes are headache $(6 \%)$, dizziness $(6 \%)$, abdominal pain $(9 \%)$, flatulence and constipation ${ }^{(5,13)}$.

Still, clinical studies show that $\mathrm{Creon}^{\circledR}$ is well tolerated with very few adverse events related, regardless of patient age ${ }^{(20)}$.

\section{CONCLUSION}

There are no studies in the literature that compare the cost of treating these patients. Therefore, this finding may contribute to new studies to prove that there is a need to stratify the degree of exocrine pancreatic insufficiency and improve methods of determining doses of pancreatic enzymes, in order to save public money and improve the quality of life of these patients.

In conclusion, the patients that underwent pancreatectomy due to tumor or chronic pancreatitis have similar treatment and there is no statistically significant difference between the cost of enzyme replacement therapy in patients after pancreatectomy with and without previous chronic pancreatitis.

\section{Authors' contributions}

Fragoso AV: data collection, research and writing. Pedroso MR: writing. Herman P: writing. Montagnini AL: writing. 
Fragoso AV, Pedroso MR, Herman P, Montagnini AL. Comparação do custo do tratamento com reposição de enzimas pancreáticas em pacientes submetidos a pancreatectomia por tumor pancreático e pancreatite crônica. Arq Gastroenterol. 2016,53(2): 94-7.

RESUMO - Contexto - Dentre as complicações pós-operatórias tardias da pancreatectomia estão as insuficiências pancreáticas exócrina e endócrina. O reconhecimento da presença de insuficiência pancreática exócrina impõe, como tratamento padrão, a reposição de enzimas pancreáticas. Pacientes portadores de pancreatite crônica, com dor clinicamente intratável ou com alguma complicação com indicação de tratamento cirúrgico, podem vir a apresentar insuficiência pancreática exócrina ou ter essa condição agravada requerendo adequação de dose de enzimas pancreáticas. Objetivo - O objetivo deste estudo é comparar a dose necessária de enzima pancreática e o custo do tratamento de reposição enzimática em pacientes pancreatectomizados, com e sem pancreatite crônica. Métodos - Estudo transversal observacional. No primeiro semestre de 2015 pacientes acompanhados no ambulatório de Cirurgia do Aparelho Digestivo do HC-FMUSP, submetidos a pancreatectomia há pelo menos 6 meses e em terapia de reposição enzimática foram incluídos nessa casuística. O estudo foi aprovado pelo Comitê de Ética. Os pacientes foram divididos em dois grupos, de acordo com a presença ou ausência de pancreatite crônica prévia à cirurgia pancreática. Para este estudo, $P<0,05$ foi considerado como estatisticamente significante. Resultados - O custo anual do tratamento foi $\mathrm{R} \$ 2150,51 \pm 729,39 ; \mathrm{R} \$ 2118,18 \pm 731,02$ em pacientes sem pancreatite crônica e R $\$$ $2217,74 \pm 736,30 \mathrm{em}$ pacientes com pancreatite crônica. Conclusão - Não houve diferença estatisticamente significante no custo do tratamento de reposição enzimática entre pacientes pancreatectomizados com ou sem pancreatite crônica prévia à indicação cirúrgica.

DESCRITORES - Pancreatectomia. Terapia de reposição de enzimas. Pancreatite crônica.

\section{REFERENCES}

1. Alexakis N, Halloran C, Raraty M, Ghaneh P, Sutton R, Neoptolemos JP. Current standards of surgery for pancreatic cancer. Br J Surg. 2004;91:1410-27.

2. Belyaev O, Herzog T, Chromik AM, Meurer K, Uhl W. Early and late postoperative changes in the quality of life after pancreatic surgery. Langenbecks Arch Surg. 2013;398:547-55.

3. Benini L, Amodio A, Campagnola P, Agugiaro F, Cristofori C, Micciolo R, et al. Fecal elastase-1 is useful in the detection of steatorrhea in patients with pancreatic diseases but not after pancreatic resection. Pancreatology. 2012;13:38-42.

4. Berry AJ. Pancreatic Enzyme Replacement Therapy During Pancreatic Insufficiency. Nutr Clin Pract. 2014;29:312-21.

5. Braddick JA, Flaherty AMC. Management of Pancreatic Exocrine Insufficiency. Oncol Nurs Forum. 2013;40:116-9. [Internet]. [Access 2015 Sep 10]. Available from: http://www.medscape.com/viewarticle/782772

6. Brelian D, Tenner S. Diarrhoea due to pancreatic diseases. Best Pract Res Clin Gastroenterol. 2012;26:623-31.

7. Conlon KC, Klimstra DS, Brennan MF. Long-term survival after curative resection for pancreatic ductal adenocarcinoma. Clinicopathologic analysis of 5-year survivors. Ann Surg. 1996;223:273-9.

8. D'Haese JG, Ceyhan GO, Demir IE, Layer P, Uhl W, Löhr M, et al. Pancreatic Enzyme Replacement Therapy in Patients With Exocrine Pancreatic Insufficiency Due to Chronic Pancreatitis: A 1-Year Disease Management Study on Symptom Control and Quality of Life. Pancreas. 2014;43:834-41

9. Deviere J. Argon plasma coagulation therapy for ablation of Barrett's oesophagus. Gut. 2002;51:763-4.

10. Domínguez-Muñoz JE, Iglesias-García J, Iglesias-Rey M, Vilariño-Insua M. Optimising the therapy of exocrine pancreatic insufficiency by the association of a proton pump inhibitor to enteric coated pancreatic extracts. Gut. 2006;55:1056-7.

11. Evans JP, Burke W, Chen R, Bennett RL, Schmidt RA, Dellinger EP, et al. Familial pancreatic adenocarcinoma: association with diabetes and early molecular diagnosis. J Med Genet. 1995;32:330-5.

12. Evans JD, Wilson PG, Carver C, Bramhall SR, Buckels JA, Mayer AD, et al. Outcome of surgery for chronic pancreatitis. Br J Surg. 1997;84:624-9.

13. Fieker A, Philpott J, Armand M. Enzyme replacement therapy for pancreatic insufficiency: Present and future. Clin Exp Gastroenterol. 2011;4:55-73.

14. Friess $\mathrm{H}$, Michalski $\mathrm{CW}$. Diagnosing exocrine pancreatic insufficiency after surgery: when and which patients to treat. HPB (Oxford). 2009;11:7-10.

15. Ghaneh $P$, Neoptolemos JP. Pancreatic exocrine insufficiency following pancreatic resection. Digestion. 1999;60:104-10.

16. Halloran CM, Cox TF, Chauhan S, Raraty MGT, Sutton R, Neoptolemos JP, et al. Partial pancreatic resection for pancreatic malignancy is associated with sustained pancreatic exocrine failure and reduced quality of life: A prospective study. Pancreatology. 2011;11:535-45

17. Huang JJ, Yeo CJ, Sohn TA, Lillemoe KD, Sauter PK, Coleman J, et al. Quality of life and outcomes after pancreaticoduodenectomy. Ann Surg. 2000;231:890-8.

18. Keim V, Klar E, Poll M, Schoenberg MH. Postoperative care following pancreatic surgery: surveillance and treatment. Dtsch Arztebl Int. 2009;106:789-94.

19. King JC, Hines OJ. Predicting exocrine insufficiency following pancreatic resection. J Surg Res. 2010;164:2010-2.

20. Kuhn RJ, Gelrud A, Munck A, Caras S. CREON (pancrelipase delayed-release capsules) for the treatment of exocrine pancreatic insufficiency. Adv Ther. 2010;27:895-916

21. Malka D, Hammel P, Maire F, Rufat P, Madeira I, Pessione F, et al. Risk of pancreatic adenocarcinoma in chronic pancreatitis. Gut. 2002;51:849-52.
22. Mansfield EL. A Practical Guide to the Invariant Calculus. Part of Cambridge Monographs on Applied and Computational Mathematics. 2010.

23. Moossner J, Keim V. Pancreatic enzyme therapy. Dtsch Arztebl Int. 2010;108:578-82.

24. Nakajima K, Oshida H, Muneyuki T, Kakei M. Pancrelipase: An evidence-based review of its use for treating pancreatic exocrine insufficiency. Core Evid. 2012;7:77-91.

25. Neoptolemos JP, Stocken DD, Friess H, Bassi C, Dunn JA, Hickey H, et al. A randomized trial of chemoradiotherapy and chemotherapy after resection of pancreatic cancer. N Engl J Med. 2004;350:1200-10.

26. Nitecki SS, Sarr MG, Colby TV, van Heerden JA. Long-term survival after resection for ductal adenocarcinoma of the pancreas. Is it really improving? Ann Surg. 1995;221:59-66.

27. Nordback I, Parviainen M, Piironen A, Räty S, Sand J. Obstructed pancreaticojejunostomy partly explains exocrine insufficiency after pancreatic head resection. Scand J Gastroenterol. 2007;42:263-70.

28. function and quality of life. Br J Surg. 2013;100:1064-70

29. Partelli S, Frulloni L, Minniti C, Bassi C, Barugola G, D'Onofrio M, et al. Faecal elastase-1 is an independent predictor of survival in advanced pancreatic cancer. Dig Liver Dis [Internet]. Editrice Gastroenterologica Italiana; 2012;44:945-51.

30. Ramesh H, Reddy N, Bhatia S, Rajkumar JS, Bapaye A, Kini D, et al. A 51-week, open-label clinical trial in India to assess the efficacy and safety of pancreatin 40000 enteric-coated minimicrospheres in patients with pancreatic exocrine insufficiency due to chronic pancreatitis. Pancreatology. 2013;13:133-9.

31. Riall TS, Cameron JL, Lillemoe KD, Winter JM, Campbell KA, Hruban RH, et al. Resected periampullary adenocarcinoma: 5-year survivors and their 6- to 10-year follow-up. Surgery. 2006;140:764-72.

32. Seiler CM, Izbicki J, Varga-Szabõ L, Czakõ L, Fiõk J, Sperti C, et al. Randomised clinical trial: A 1-week, double-blind, placebo-controlled study of pancreatin $25000 \mathrm{Ph}$. Eur. minimicrospheres (Creon $25000 \mathrm{MMS}$ ) for pancreatic exocrine insufficiency after pancreatic surgery, with a 1-year open-label extension. Aliment Pharmacol Ther. 2013;37:691-702.

33. Sikkens ECM, Cahen DL, Eijck C, Kuipers EJ, Bruno MJ. The Daily Practice of Pancreatic Enzyme Replacement Therapy After Pancreatic Surgery: a Northern European Survey. J Gastrointest Surg. 2012;16:1487-92.

34. Speicher JE, Traverso LW. Pancreatic exocrine function is preserved after distal pancreatectomy. J Gastrointest Surg. 2010;14:1006-11.

35. Strate T, Bachmann K, Busch P, Mann O, Schneider C, Bruhn JP, et al. Resection vs Drainage in Treatment of Chronic Pancreatitis: Long-term Results of a Randomized Trial. Gastroenterology. 2008;134:1406-11.

36. Tersmette AC, Petersen GM, Offerhaus GJ, Falatko FC, Brune KA, Goggins M, et al. Increased risk of incident pancreatic cancer among first-degree relatives of patients with familial pancreatic cancer. Clin Cancer Res. 2001;7:738-44.

37. Trede M, Schwall G, Saeger HD. Survival after pancreatoduodenectomy. 118 consecutive resections without an operative mortality. Ann Surg. 1990;211:447-58.

38. Whelan AJ, Bartsch D, Goodfellow PJ. Brief report: a familial syndrome of pancreatic cancer and melanoma with a mutation in the CDKN2 tumor-suppressor gene. N Engl J Med. 1995;333:975-7.

39. Wier HA, Kuhn RJ. Pancreatic enzyme supplementation. Curr Opin Pediatr. 2011;23:541-4.

40. Yeo CJ, Cameron JL, Sohn TA, Lillemoe KD, Pitt HA, Talamini MA, et al. Six hundred fifty consecutive pancreaticoduodenectomies in the 1990s: pathology, complications, and outcomes. Ann Surg. 1997;226:248-57; discussion 257-60.

41. Yeo CJ, Sohn TA, Cameron JL, Hruban RH, Lillemoe KD, Pitt HA. Periampullary adenocarcinoma: analysis of 5-year survivors. Ann Surg. 1998;227:821-31. 